http://dx.doi.org/10.12775/szhf.2017.010

\author{
JUSTYNA NowaK \\ Uniwersytet MikoŁaja Kopernika, Toruń, Polska \\ NOWAK.JUSTYNA2@GMAIL.COM
}

\title{
Pojęcie władzy w ujęciu Michela Foucaulta i Hannah Arendt
}

\section{Wstęp - pojęcie przemocy}

W niniejszym artykule przedstawiono konfrontację myśli Hannah Arendt oraz Michela Foucaulta. Zaprezentowane ujęcie teorii francuskiego filozofa skupia się na zjawisku władzy postrzeganym jako narzędzie kontroli i nadzoru, wymagającym od nieświadomych jednostek bezwzględnego posłuszeństwa. Diagnozę Foucaulta ukazano jako kontrastującą $\mathrm{z}$ teorią władzy Arendt, dla której rządzenie musi wynikać $\mathrm{z}$ wolności. Z tego powodu przedstawione rozważania w dużej mierze skupiają się na wyizolowaniu kategorii przemocy z pojęcia władzy, co odpowiada filozoficznym i politycznym staraniom Arendt. Przeprowadzone poniżej rozpoznanie niesłusznego połączenia tych dwóch zjawisk oraz wynikające z niego konsekwencje wyznaczają oś tej pracy.

W społeczeństwie przyjęła się praktyka kojarzenia pojęcia przemocy ze światem zwierząt, z którego miałaby ona rzekomo promieniować na rzeczywistość ludzką. Ta radykalna dychotomia pomiędzy dwoma różnymi porządkami rzeczywistości jest jednocześnie wzmagana przez społeczny dyskurs, 
a także - w zależności od potrzeb - przez niego negowana. Utożsamienie brutalności i okrucieństwa ze światem przyrody przychodzi nam o tyle łatwo, o ile od początku przyjmujemy założenie, że między światem ludzkim a zwierzęcym rozpościera się przepaść, którą ustanawia „rozum” ${ }^{1}$ Z drugiej strony uczeni reprezentujący najrozmaitsze dyscypliny nauk przyrodniczych, a zwłaszcza etologii ${ }^{2}$, zgodnie bronią tezy, że skłonność rodzaju ludzkiego do agresji, przemocy i wojny nie ma żadnego biologicznego podłoża i jest czystym produktem (rzekomo „zdegenerowanej”) ludzkiej kultury. Tym bardziej nie powinny szokować ogromne sumy pieniędzy cyklicznie wydawane na badania mające na celu uprawomocnienie tezy, że przemoc jest tym, co określa nas bardziej niż moglibyśmy przypuszczać. Dotyczy to głównie badań z zakresu nauk humanistycznych oraz przyrodniczych, które mają na celu porównanie zachowań agresywnych w świecie zwierzęcym z przemocą „,czysto" kulturową ${ }^{3}$. Dzięki tego typu analizom w społeczeństwie upowszechnił się pogląd, według którego agresywność jest instynktownym popędem, porównywalnym z popędem płciowym oraz potrzebą odżywiania. Ten przykład unaocznia opłakane skutki przenoszenia kategorii „siły” na procesy biologiczne $e^{4}$ W odniesieniu do nich kategoria ta traci jednak sens, ponieważ przestaje być mierzalna ${ }^{5}$.

Rozmaite pojęcia nawiązujące do rzekomego okrucieństwa świata zwierząt, które bezrefleksyjnie wykorzystuje się w społecznym dyskursie, prowadzą do fikcyjnej opozycji „dobrych ludzi” i „złych zwierząt”. „Zwierzęcość” staje się tutaj matrycą dla opisu wszelkich zjawisk rzeczywistości uznawanych za niepożądane, „nieludzkie”. Podobnie przedstawia się problem dotyczący powszechności występowania przemocy. Nie tylko przywykliśmy do generalizacji tego pojęcia, lecz także uważamy je za najpierwotniejsze zjawisko, stanowiące podstawę wszelkich działań człowieka oraz warunek jego ewolucji. Dogmatycznie uznawany za oczywistość imperatyw „walki o przetrwanie” ekstrapoluje się przy tym często na obszar polityczno-społeczny. Zwróćmy uwagę na specjalny status, jakim cieszą się bohaterowie polegli w walce o „dobrą sprawę". Idee poświęcenia i woli walki wykorzystywane są do tworzenia mitów kulturowych i politycznych, które przyczyniają się do wzmocnienia

${ }^{1}$ H. Arendt, O przemocy. Nieposłuszeństwo obywatelskie, przeł. A. Łagocka, W. Madej, Warszawa 1998, s. 79.

${ }^{2}$ K. Lorenz, Tak zwane zło, przeł. A. Tuszyńska, Warszawa 1972.

${ }^{3}$ H. Arendt, O przemocy..., s. 77.

${ }^{4}$ Tamże, s. 78.

${ }^{5}$ Por. analizy zawarte w 5. części niniejszego artykułu. 
(różnie pojmowanej) tożsamości narodowej, ale mogą być również społecznie szkodliwe - często służą hierarchizacji społeczeństwa. Spójrzmy tylko, jak to sprawnie działa - np. za pomocą stosunku jednostki do możliwego zaangażowania w działania wojenne określa się jej przydatność społeczną (służenie ojczyźnie bądź dezercja - oba zjawiska są odpowiednio emocjonalnie nacechowane). Poddanie się woli suwerena przyjmujemy w społeczeństwie jako coś oczywistego i niepodlegającego kwestionowaniu. Wszelkie odstępstwa od tej normy sprzyjają społecznej banicji. W tego typu określeniach jednostki ludzkiej tkwi przekonanie, że można ludzi uczynić „lepszymi” bądź "gorszymi", a więc stworzyć ich i skatalogować na wzór przedmiotów ${ }^{6}$. Ponadto działania oparte na ideach poświęcenia i woli walki aktualizują mit o przemocy jako naczelnej zasadzie przetrwania i rozwoju.

Jeżeli zgodzimy się z tezą, że agresja jest głównym czynnikiem, który determinuje naszą społeczną i polityczną aktywność (rywalizacja majątkowa, walka o prestiż, uznanie i władzę etc.), wówczas wartość innych idei automatycznie ulega dewaluacji, czyniąc je "nieatrakcyjnymi” dla politycznego dyskursu. Jeśli jednak spojrzymy na ten problem z drugiej strony, może okazać się, że wpadliśmy w pułapkę mitu - przyznając przemocy tak wysoki status w piramidzie wartości, pozwalamy jej bowiem przeniknąć na wszystkie płaszczyzny życia człowieka. To, co miało być „jądrem ciemności”, staje się $\mathrm{w}$ tej perspektywie zasadą rządzącą uniwersum ludzkiej kultury. Jeśli przemoc jest wszechobecna w naszym życiu, oznacza to, że już dawno polegliśmy na polu wartości, a sama idea człowieczeństwa przestała mieć jakiekolwiek znaczenie.

Teza o mitotwórczej roli zjawiska przemocy nie została $\mathrm{w}$ tym artykule postawiona bezzasadnie, a będzie stanowić przyczynek do rozważań na temat zjawiska władzy. Poniższy artykuł zawiera polemiczne rozważania oparte na komparatystycznych analizach teorii władzy Hannah Arendt oraz Michela Foucaulta. W głównej mierze skupia się jednak na rekonstrukcji poglądów filozofki na temat samego terminu rządzenia i przemocy oraz przerwania istniejącej między nimi relacji $(4,5,6)$. Na zasadzie kontrapunktu przedstawione zostały poglądy Foucaulta na temat relacji wiedzy/władzy oraz władzy/ prawdy $(2,3)$. Przytoczone porównanie pozwoli na dokonanie analizy tych dwóch różnych od siebie sposobów pojmowania tego, co nazywamy rządzeniem. W trakcie analizy wyłoni się również szereg pojęć, które tradycyjnie wykorzystywano w opisie władzy, takich jak moc, siła, przemoc. Odwołując

\footnotetext{
${ }^{6}$ H. Arendt, Kondycja ludzka, przeł. A. Łagodzka, Warszawa 2000, s. 207.
} 
się do koncepcji Arendt, spróbuję pokazać, że utożsamianie tych pojęć z fenomenem władzy jest nieuzasadnione i rodzi wiele niejasności (5).

\section{Czym jest władza?}

Relacja jednostka-społeczeństwo była omawiana już przez Platona, który dokonał słynnego wglądu w duszę obywateli polis, porównując jej strukturę $\mathrm{z}$ ustrojem państwa ${ }^{7}$. Podobne założenia znajdujemy również u Arystotelesa czy św. Augustyna, jednakże dopiero w dobie nowożytnej można dostrzec formowanie się teorii społecznych, które nie uwzględniają metafizycznego gruntu. Współczesna filozofia społeczna ujawniła się w Rozprawie o pochodzeniu i podstawach nierówności J. Rousseau, następnie rozkwitła dzięki pismom filozoficznym Kanta czy myślicielom romantycznym, a pełne światło rzuciły na nią teksty polityczne Hegla i Marksa ${ }^{8}$. Należy jednak odróżnić dwa opozycyjne porządki rozumienia władzy, jakie dokonały się w nowożytnej myśli filozoficznej. Pierwszym z nich będzie stanowisko Spinozy, gdzie władza pojmowana jest w odniesieniu do mocy, którą dysponuje jednostka. Tutaj władzę polityczną określa sinusoida jej działania - zależnie od nastrojów i możliwości jednostek siła opada (słabnie) bądź rośnie (umacnia się). Z drugiej strony będzie to rozumienie wywiedzione od Hobbesa, gdzie władza polityczna jest rozumiana jako bezwzględne panowanie nad jednostką. W tym przypadku będzie ona tożsama z podporządkowaniem się woli innych. Zauważmy, że w tym rozumieniu jednostka nie decyduje o swoim postępowaniu, a jest w całości kontrolowana przez aparat władzy. Zachodzi więc tutaj ogromna ingerencja w wolność i suwerenność jednostki.

Współcześnie możemy zaobserwować wzrost zainteresowania problematyką władzy w filozofii, socjologii i - rzecz jasna - w politologii. Wydaje się przy tym, że dyskusję na ten temat zdominował „demaskatorski” pogląd o wszechobecności relacji panowania w świecie społecznym. Do koniunktury takiego pesymistycznego ujęcia problemu przyczyniła się niewątpliwie ogromna popularność postnietzscheańskiej analityki władzy Foucaulta, ale również wspomniane już przekonanie o moralnej wyższości gatunku ludz-

\footnotetext{
${ }^{7}$ Platon, Państwo, przeł. W. Witwicki, Warszawa 1958, 441 C.

${ }^{8}$ S. Czerniak, R. Michalski, Filozofia jako samokrytyka rozumu. Meandry doktrynalnej ewolucji teorii krytycznej, Lubicz 2014, s. 218.
} 
kiego nad światem zwierzęcym. Źródeł tego poglądu możemy doszukiwać się ponadto $\mathrm{w}$ zbiorowej pamięci narodów - odczuwamy spętanie sieciami władzy, ponieważ we współczesnym społeczeństwie pobrzmiewają jeszcze echa dwudziestowiecznych totalitaryzmów, które umacniają nasze poczucie zagrożenia i zniewolenia ze strony zinstytucjonalizowanych systemów władzy państwowej. Podobny pogląd głosił już Jean Paul Sartre - co pomija się na ogół w literaturze tematu - uznając władzę za jedną z najważniejszych zasad projektowania egzystencji jednostki ${ }^{9}$ Główną słabością jego teorii było jednak to, że w swoich rozważaniach nie odróżnił precyzyjnie przemocy od władzy, co doprowadziło go do abstrakcyjnego przeciwstawienia władzy/ przemocy, rzekomo przenikającej wszystkie relacje międzyludzkie, ideałowi bezwarunkowej wolności jednostkowej egzystencji.

Tego rodzaju opozycji nie znajdziemy w teorii Michela Foucaulta, który badał relacje zachodzące między władzą a językiem i sposobem formowania się wiedzy, włączając w to rozmaite dyskursy nauki oraz instytucje społeczne (szpitale, więzienia, szkoły). W jednym ze swoich późniejszych tekstów filozof zadaje ważne dla naszych wywodów pytanie: „czym jest owa władza, której agresywność, siła, bezwzględność i absurdalność ujawniły się konkretnie w ciągu ostatnich czterdziestu lat jednocześnie po stronie bankrutującego nazizmu i po stronie obezwładniającego stalinizmu?" ${ }^{10}$. Foucault odnosi się w tym pytaniu do władzy totalitarnej, ale możemy przyjąć, że w istocie ma na myśli wszelkie formy przejawiania się władzy. Uprzedzając dalsze, bardziej szczegółowe analizy, wskażemy najbardziej zwięzłą odpowiedź filozofa na postawione przez niego samego pytanie. Władza stanowi dynamiczną podstawę wszelkich interakcji i praktyk społecznych, która umożliwia zarazem ukonstytuowanie się podmiotowości uczestniczących w nich jednostek. Wywalczone w różnych miejscach przestrzeni społecznej pozycje władzy łączą się na podobieństwo sieci w elastyczny, pozbawiony centrum system, który zniewala wszystkie bez wyjątku podlegające mu jednostki. Foucault wynosi zatem pojęcie władzy do rangi naczelnej, niemal metafizycznej zasady, któ-

\footnotetext{
${ }^{9}$ Pojęcie władzy (jako przemocy) pojawia się u Sartre’a w momencie, gdy opisuje on proces "projektowania siebie” przez jednostkę, która „przegląda się” w oczach Innego, a zarazem sama staje się „zwierciadłem” dla jego spojrzenia. Ingerencja Innego jest rozumiana tutaj jako utajona przemoc, jako „urabianie bytu”. Zagadnienie to pojawia się również w jego fenomenologicznej teorii miłości. Emocjonalna dialektyka miłosnego „konfliktu” przyjmuje nieuchronnie formę sadyzmu - Inny „wdziera się” w obiekt swoich uczuć, próbuje posiąść w tym akcie wolność osoby kochanej. Por. J.-P. Sartre, Byt i nicość, przeł. J. Kiełbasa, Kraków 2007, s. 457.

${ }^{10}$ M. Foucault, Trzeba bronić społeczeństwa, przeł. M. Kowalska, Warszawa 1998, s. 25.
} 
ra ma wyjaśniać wszystkie praktyki społeczne wymagające kontroli, nadzoru i kooperacji. W takiej perspektywie uwolnienie się od wszechobecnych struktur władzy przypomina bezowocną pracę Syzyfa ${ }^{11}$.

Foucault zakłada ponadto, że porządek społeczny tworzy się już na poziomie języka, a ściślej - na płaszczyźnie społecznych form wiedzy. Nie jest to założenie błędne zwłaszcza na polu teorii feministycznych i codziennej praktyki, które pokazały, w jaki sposób może odbywać się wykluczenie czy opresja kobiet ${ }^{12}$, jednakże jego abstrakcyjność powoduje, że staje się mało realistyczne i podatne na krytykę - próba wyjaśnienia złożonych praktyk społecznych za pomocą jednej zasady musi bowiem prowadzić do teoretycznych uproszczeń.

Wydaje się, że tego rodzaju pułapki uniknęła Hannah Arendt, próbując usystematyzować i odróżnić od siebie pokrewne znaczeniowo pojęcia przemocy, władzy, siły i mocy ${ }^{13}$. Filozofka pokazuje, że znaczenia tych terminów odnoszą się w rzeczywistości do odmiennych, choć powiązanych ze sobą zjawisk. Używanie ich jako synonimów owocuje teoretycznym „zaślepieniem” i ostatecznie służy podtrzymaniu mitu o przemocy ${ }^{14}$.

\section{Relacje władzy u Michela Foucaulta}

Zacznijmy od przedstawienia podstawowych założeń Foucaulta na temat relacji wiedza/władza oraz prawda/władza. W drugiej części artykułu zostały przedstawione dwa modele nowożytnego pojmowania władzy. W pierwszym modelu, pochodzącym od Hobbesa, uznaje się bezwzględną zależność jednostki od „suwerena” oraz przyjmuje założenie, że wszelka władza zostaje przejęta na drodze przemocy. Drugi model odwołuje się natomiast do koncepcji umowy społecznej, dopuszczając tym samym wolne od przemocy ustanowienie władzy ${ }^{15}$. Foucault nie reprezentuje żadnego ze wskazanych ujęć, a proponuje nowy model wywiedziony wprost z filozofii Nietzschego. Nietz-

\footnotetext{
${ }^{11}$ S. Czerniak, R. Michalski, dz. cyt., s. 239.

${ }^{12} \mathrm{~W}$ tym miejscu należałoby wymienić wiele publikacji zawierających podobne założenia. Bezpośrednio do analiz Foucaulta nawiązuje: Judith Butler, Uwikłani w płeć, przeł. K. Krasuska, Warszawa 2008.

${ }^{13} \mathrm{H}$. Arendt, O przemocy..., s. 56.

14 Tamże, s. 56.

${ }^{15}$ Szerzej na ten temat: S. Czerniak, R. Michalski, dz. cyt., s. 244.
} 
scheańska teoria woli mocy (Wille zur Macht), gdzie Macht jako moc/władza jest rozumiana jako ontologiczna zasada, opisuje władzę jako wszechobecną siłę $^{16}$. To właśnie Foucault znalazł dla tej koncepcji nowe miejsce i ulokował ją w dziedzinie filozofii społecznej.

Przyjrzyjmy się jak on sam przedstawia swoją teorię:

Co to jest władza? [...] Chodzi o to, by określić, czym są w swoich mechanizmach, w swoich skutkach, w swoich relacjach rozmaite narzędzia władzy, działające na różnych poziomach społeczeństwa, w różnych dziedzinach i wymiarach. Grosso modo, sądzę, że w tym wszystkim chodzi o następujący problem: czy analizę władzy albo władz można, w taki czy inny sposób, wywieść z ekonomii? ${ }^{17}$.

Aby odpowiedzieć na to pytanie, Foucault próbuje „genealogicznie” odnaleźć źródła władzy na płaszczyźnie działania ${ }^{18}$, a nie w sferze ekonomii (marksizm) czy zinstytucjonalizowanego prawa (Max Weber). Oznacza to, że w swoich dociekaniach daje on pierwszeństwo analizie synchronicznej kosztem badań diachronicznych, chociaż poświęca im w swoich tekstach wiele uwagi. Na przykład, genealogia władzy zawarta w Nadzorować $i$ karać odtwarza wprawdzie historyczną ewolucję systemu penitencjarnego, ale właściwe znaczenie i funkcja władzy zostają ukazane w „bezczasowej” perspektywie konkretnych działań - sam proces dziejowy zamienia się u Foucaulta $\mathrm{w}$,atemporalny strumień" utrwalonych w piśmie (a ściślej w archiwach) językowych wypowiedzi. Opisywana w ten sposób władza nie tylko panuje $\mathrm{w}$ wielu różnych dziedzinach życia społecznego, ale zarazem jest wynikiem nieustannej (symbolicznej) walki pomiędzy jednostkami, która musi być bezustannie ponawiana, aby wytworzyć stałość i jedność medium władzy ${ }^{19}$. W rezultacie strategicznych zmagań tworzy się „sieć władzy” w równym stopniu czuła na społeczne modyfikacje, co przez nie utrwalana. Czytając Foucaulta można odnieść wrażenie, że władzę należałoby w zasadzie interpretować wyłącznie przy użyciu takich pojęć, jak konflikt, walka, wojna ${ }^{20}$. Foucault wydaje się utożsamiać te pojęcia, tymczasem opisywane przez niego zjawiska

\footnotetext{
${ }^{16}$ F. Nietzsche, Wola mocy. Próba przemiany wszystkich wartości, przeł. S. Frycz i K. Drzewiecki, Kraków - Warszawa 1910.

${ }^{17}$ M. Foucault, Trzeba bronić społeczeństwa, s. 25.

18 Tamże, s. 244.

${ }^{19}$ Tamże, s. 244.

${ }^{20}$ Tamże, s. 28.
} 
dotyczą - z perspektywy koncepcji Arendt - zjawiska przemocy, a nie władzy jako takiej ${ }^{21}$.

Przyjrzymy się jeszcze relacji wiedza/władza. To właśnie za pomocą tej zbitki pojęciowej Foucault analizuje systemy konkretnych praktyk społecznych. W zasadzie wykorzystuje ją jako uniwersalny klucz interpretacyjny, który ma odsłonić ukryte mechanizmy kształtujące nasz sposób mówienia o rzeczywistości oraz jej rozumienia - to znaczy ujawnić to, co sprawiło, że dane formy wiedzy i władzy przetrwały w takiej postaci, w jakiej je obecnie znamy. Wiedza ma zatem nieodłącznie splatać się z władzą w tym sensie, że tworzenie wiedzy i jej przekazywanie odbywa się zawsze w pewnych instytucjonalnych ramach otoczonych nimbem autorytetu niepodważalnej prawdy. Wiedza nie sprowadza się tylko, jak chcieliby skrajni pozytywiści, do opisu faktów, wyjaśniania i prognozowania obiektywnych procesów, ale dogłębnie kształtuje nasz sposób rozumienia siebie, świata i zamieszkujących go ludzi, dostarcza ponadto kryteriów oceny oraz praktycznych wzorców dla szeregu jednostkowych, społecznych, politycznych, prawnych, ekonomicznych etc. działań, które tworzą znany nam świat kultury. Dla Foucaulta najważniejszą prerogatywą wiedzy jest jednak to, że stanowi ona doskonałe, choć często ukryte, narzędzie sprawowania kontroli społecznej - najważniejszym jej obiektem okazuje się nie tyle ludzka psychika, emocje, poglądy, lecz ciało pojęte jako nieredukowalne podłoże wszelkiego działania. To właśnie na cielesności władza odciska swoje największe piętno, dlatego filozof poświęca niezwykle dużo miejsca opisom rozmaitych praktyk dyscyplinowania ciała - począwszy od mniej lub bardziej wyrafinowanych technik torturowania, ascezy, poprzez strategiczne ujarzmianie niepokornych lub niewydajnych ciał chorych psychicznie, uczniów, robotników, żołnierzy, po bardziej współczesne formy biopolityki. We wszystkich przypadkach pod pozorami „troski o dobro" kryje się, według Foucaulta, intencja sprawowania kontroli nad ciałem, nad jego odruchami i działami. Ujarzmianie „uległych ciał” może się jednak powieść tylko wtedy, gdy opiera się ono na usankcjonowanym - a najlepiej zinstytucjonalizowanym - systemie wiedzy.

W świetle koncepcji Arendt francuski filozof popełnia w swojej argumentacji dwa kluczowe błędy. Po pierwsze, sytuując relacje władzy na przedpolitycznym poziomie procesów cielesnych, zaciera granice, w obrębie których można sensownie definiować władzę jako naczelną zasadę polityczności traci zatem zarówno możliwość trafnego opisu samej władzy, jak i działania

\footnotetext{
${ }^{21}$ Por. następny rozdział.
} 
politycznego, które konstytuuje obszar ludzkiej wolności. Po drugie, łącząc władzę z wiedzą pod kątem potencjalnej przemocy czy przymusu, pomija, a właściwie neguje drugi, „wolnościowy” aspekt wiedzy. Arendt, podobnie jak Foucault, jest sceptycznie nastawiona do oświeceniowego przekonania, że postęp poznania sprzyja „z konieczności” rozwojowi moralnemu ludzkiego gatunku, równie zdecydowanie obnaża instrumentalizm nauki, jej uwikłanie w pozateoretyczne zależności, ale zarazem pokazuje, że wiedza oparta na „autentycznym myśleniu” 22 jest niezbędnym medium realizacji wolności człowieka.

Sam Foucault zdawał się jednak dostrzegać wady własnej koncepcji. $\mathrm{W}$ późnym okresie twórczości odstąpił od nazbyt dosłownie odczytywanej przez interpretatorów figury savoir/pouvoir i zastąpił ją pojęciem rządzenia ludźmi za pomocą pojęcia prawdy - a tym samym zastąpił pojęcie władzy (le savoir) kategorią rządzenia (le gouvernement) ${ }^{23}$. Filozof wprowadził w tym celu pojęcie aleturgii, które oznacza „[...] zespół możliwych werbalnych lub niewerbalnych procedur, za pomocą których wydobywamy na światło dzienne to, co - w opozycji do fałszu, tego, co ukryte, niewypowiadalne, nieprzewidywalne, zapomniane - uznajemy za prawdę"24. Aleturgia jako procedura pozyskiwania ukrytych informacji poprzedza wiedzę i naukę. W celu uzasadnienia swojej teorii (zmodyfikowanej o pojęcie prawda/rządzenie) Foucault charakteryzuje zespół „aleturgicznych” praktyk, używając opisu socjologiczno-historycznego. Za przykłady służą mu między innymi procesy czarownic palonych na stosie, działalność wróżbitów, ale również praktyki ekspertów z dziedziny psychologii ${ }^{25}$. Jego zdaniem praktyki wydobywania prawdy mają łączyć się ze sposobem pozyskiwania władzy. Kolejny raz widzimy jednak pomieszanie odmiennych porządków pojęciowych - praktyki palenia czarownic na stosie czy torturowania politycznych więźniów nie są przecież sposobem sprawowania władzy, ale wykorzystaniem narzędzi przemocy. Sposoby wykorzystywania politycznej hegemoni przynależą do zupełnie innego porządku niż sama idea władzy.

Musimy przyznać, że nawet bez wysuwania zarzutów o brak ścisłości oraz niedostateczną definicję pojęć, relacje władzy w koncepcji Foucaulta same wpadają $\mathrm{w}$ zastawione przez siebie sidła. Brakuje bowiem u niego pytania

\footnotetext{
${ }^{22}$ H. Arendt, Kondycja ludzka, s. 351.

${ }^{23}$ M. Foucault, Rzadzenie żywymi, przeł. M. Herer, Warszawa 2014, s. 33.

${ }^{24}$ Tamże, s. 33.

${ }^{25}$ M. Foucault, Rządzenie żywymi, s. 30.
} 
o legitymizację władzy, o faktycznego jej beneficjenta i głównego poszkodowanego ${ }^{26}$. W rezultacie struktury władzy stają się anonimowe, a ich „antypsychologiczny" opis pomija całkowicie rolę jednostki w procesie formowania się aleturgicznych procedur rządzenia. Brakuje tutaj refleksji nad tym, gdzie na osi relacji władzy należałoby umiejscowić takie kategorie, jak moralność jednostki, jej odpowiedzialność czy samodzielność. Nieobecność odniesienia do wartości nierozerwalnie związanych z konkretnym indywidualnym życiem powoduje, że w analizach filozofa znikają potrzeby, pragnienia i krzywdy jednostki.

\section{Władza i dziedzina publiczna u Hannah Arendt}

Hannah Arendt tropiła dawne znaczenie terminów politycznych, aby wydobyć z nich pierwszy sens, który zniekształcił się pod naporem czasu ${ }^{27}$. Dopiero po dokonaniu starannej analizy przedstawionych pojęć oraz prześledzeniu przebytej przez nie dziejowej drogi uformowała własne pojęcie polityczności. $Z$ tego powodu $\mathrm{w}$ poniższym rozdziale rozważam ważne dla filozofki pojęcie działania (praxis) oraz wyraźnie oddzielam je od bierności (różnie pojmowanej na przestrzeni wieków). Filozofka podkreśla nierozerwalny związek działania z mową oraz fakt, że lexis pozwala człowiekowi opuścić bezpieczny obszar własnego domostwa (oikos) i odważnie ruszyć ku wyzwaniom zewnętrznego świata. Bycie istotą polityczną jest dla Arendt najważniejszym powołaniem człowieka. Przestrzeń władzy (polityki) w ujęciu filozofki to miejsce pojawiania się i znikania określonych struktur społeczno- politycznych, tworzenia ich, ale i destrukcji. To pewnego typu otwarcie na obszary dotąd ukryte, które wchłaniają przestrzeń polityczną nakierowaną na człowieka, gdzie ulokuje on swoje zmumifikowane pragnienia i potrzeby.

Metafora archeologii znajduje tutaj ciekawe zastosowanie, gdyż Arendt posługuje się właściwie metodami wykopaliskowymi - wydobywa zakopane pod warstwą czasu terminy, które na drodze ewolucji pojęć i kształtowania

\footnotetext{
${ }^{26}$ Por. S. Czerniak, R. Michalski, dz. cyt., s. 250.

${ }^{27}$ Ścieżka „pojęciowa” Arendt jest bliska pojmowaniu znaczeń terminów przez Heideggera. Filozof utrzymywał bowiem, że to właśnie słowa są zapisami dawnych sposobów doświadczania świata; por. P. Sosnowska, Arendt i Heidegger. Pedagogiczna obietnica filozofii, Kraków 2015, s. 284.
} 
się przestrzeni publicznej utraciły swój blask czy dawne znaczenie. Ich renowacja jest ostrożna i dokładna. Proces oczyszczania $z$ wiekowego osadu pozwala na przyjrzenie się dokonanym w nich zmianom znaczenia. Jednym z takich terminów, na których Arendt buduje swoją koncepcję władzy jest pojęcie - właściwie dziś już zapomniane - vita activa, zawierające w sobie ideę, że człowiek realizuje wolność, gdy poświęca życie polityce ${ }^{28}$. Ta idea ujawnia przed nami mroki dzisiejszej depolityzacji (zaniku zaangażowania w sprawy publiczne), którą wspiera dominująca w liberalnych demokracjach apologia wolności negatywnej (w sensie, jaki nadał temu pojęciu Isaiah Berlin).

Już Arystoteles wyraźnie dostrzegł niebezpieczeństwa związane z polityczną biernością, która zamyka jednostkę w ciasnej przestrzeni prywatnych interesów i uniemożliwia jej osiągnięcie w pełni ludzkiej kondycji. Obok filozofii i sztuki to właśnie polityka wyrażająca się w trosce o dobro wspólne stanowi ten rodzaj aktywności, który pozwala człowiekowi zrealizować prawdziwie wolną egzystencję. Arendt przejmuje ten pogląd od Arystotelesa i powtarza za nim, że kluczową rolę w sferze politycznej odgrywa praxis (działanie) i lexis (mowa) ${ }^{29}$. Filozofka podkreśla jednak, że ta piękna idea w wersji starożytnej miała trudny do zaakceptowania przez nas, wybitnie elitarystyczny charakter. Niewolnicy, kobiety, a także rzemieślnicy i kupcy (ponieważ zajmowali się wytwarzaniem i gromadzeniem dóbr) zostali wykluczeni z możliwości realizacji swojej egzystencji w wymiarze politycznym. Arystoteles wyróżniał trzy możliwe sposoby życia (bioi) prawdziwie wolnego: a) życie polegające na radowaniu się cielesnością; b) życie poświęcone sprawom polis; c) życie filozofa poświęcone kontemplowaniu spraw wiecznych ${ }^{30}$. Ani praca, ani wytwarzanie nie były postrzegane $\mathrm{w}$ tym modelu za dostatecznie godne, by stanowić bios, czyli autentyczny sposób istnienia. Jednoznacznie wiąże się to $\mathrm{z}$ wykształceniem odmiennych od siebie dziedzin możliwości funkcjonowania człowieka w społeczeństwie, gdzie przynależał on do dwóch porządków: tego, co prywatne (idion) i tego, co wspólne (koinon) ${ }^{31}$. To rozróżnienie odpowiada podziałowi na sferę gospodarstwa domowego i dziedzinę publiczną ${ }^{32}$, które funkcjonowały jako odmienne od siebie byty, przynajmniej od czasu powstania polis. Jednocześnie miasto-państwo nie naruszało prywatnego życia obywateli, a granice każdego domu uważano za święte. Prywatność dawała

\footnotetext{
${ }^{28}$ H. Arendt, Kondycja ludzka, s. 27.

${ }^{29}$ Tamże, s. 30.

${ }^{30}$ Tamże, s. 16-17.

31 Tamże, s. 29.

32 Tamże, s. 34.
} 
względne poczucie bezpieczeństwa, ale nie oferowała możliwości zrealizowania - tak ważnego dla Greków - ideału nieśmiertelności, czyli pragnienia bycia uznanym i upamiętnionym przez przyszłe pokolenia. Dążenie do nieśmiertelności nie mogło zatem być udziałem tej części społeczeństwa, która zajmowała się wyłącznie śmiertelnymi sprawami, a więc: domostwem, stwarzaniem życia, podtrzymywaniem go. Dla Arendt najważniejszym elementem greckiego modelu wolności politycznej jest nacisk położony na działanie pojmowane jako zdolność do rozpoczynania czegoś od nowa. Praxis dąży wprawdzie do nieśmiertelności, ale - jak pisze filozofka - $\mathrm{w}$ istocie polega na nieustannym inicjowaniu czegoś nowego, na stwarzaniu nowego początku. Innym słowy, „działać politycznie” znaczy tutaj: przełamywać istniejące schematy zachowania, podejmować ważne dla całej wspólnoty decyzje, które zmieniają rzeczywistość i przyczyniają się do pomnażania dobra ogółu.

Tak pojęte działanie polityczne realizuje sie w sferze publicznej, która z upływem czasu została wyparta - jak argumentuje Arendt - przez sferę społeczną. Jej powstanie zawdzięczamy przemianom, jakie nastąpiły w nowożytnej Europie na skutek niezwykłej ekspansji gospodarczej, niekontrolowanego wzrostu populacji oraz głębokich zmian ustrojowych. Polityka przeobraziła się w technikę urządzania państwa, jej celem stało się zabezpieczenie dobrobytu obywateli, ochrona ich własności, a nie - jak u Starożytnych - troska o godziwe życie. Innymi słowy, do sfery publicznej wkroczyły zadania realizowane wcześniej wyłącznie w dziedzinie prywatnego oikos (gospodarstwa domowego), czyli - mówiąc ogólnie - kwestie ekonomiczne i socjalne.

Według Starożytnych dziedzina spraw publicznych charakteryzowała się całkowitą niezależnością od problemów związanych $\mathrm{z}$ jednostkowym przetrwaniem, $\mathrm{z}$ indywidualnymi potrzebami życiowymi. Nie tyle zatem zarządzanie, administrowanie zasobami finansowymi, ile praxis i lexis kierujące się ideałem sprawiedliwości oraz godziwego życia konstytuowały obszar tego, co polityczne ${ }^{33}$. Być istotą polityczną oznaczało tyle, ile bycie tym, kto jest zdolny do znaczącej mowy, która wywiera realne skutki w sferze publicznej

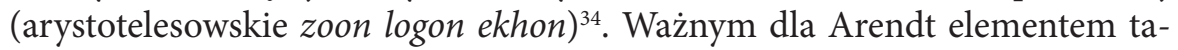
kiego ujęcia politycznej egzystencji jest nierozerwalny związek mowy z władzą, w którym ta pierwsza umożliwia drugą. Samo rządzenie definiuje się tutaj jako coś, co urzeczywistnia i podtrzymuje dziedzinę publiczną, a zatem jako instancję, która umożliwia i podtrzymuje polityczną wolność.

\footnotetext{
33 Tamże, s. 31.

${ }^{34}$ Tamże.
} 
Władza polityczna sensu stricte tworzy sieć ludzkich połączeń, ulega zaś atrofii, gdy te połączenia zanikają. Tym samym nieubłagane są dla niej prawa czasu, a jej żywotność przypomina niejako kruche życie człowieka. Tak jak on, władza jest czymś dynamicznym, przemieszczającym się, podlegającym przemianom. Samo rządzenie nie wskazuje na narzucony odgórnie, nieelastyczny konstrukt, w taki sam sposób jak pojęcie człowieka nigdy nie oznacza skończonego projektu jego egzystencji. Ten fakt ujawniają same źródła pojęcia, gdzie greckie dynamis, a łacińskie potentia ${ }^{35}$ kieruje nas ku ludzkim aktywnościom, które w pełni odsłaniają się dopiero wobec istnienia i podtrzymywania wspólnoty:

To właśnie władza trzyma ludzi razem po przeminięciu przelotnej chwili działania [...], a zarazem ludzie utrzymują ją przy życiu przez to, że pozostają razem. Ktokolwiek z jakichkolwiek powodów izoluje się i nie bierze udziału we wspólnym życiu, temu władza zostaje odjęta i staje się bezsilny, bez względu na to, jak wielką miałby moc i jak przekonujące byłyby jego racje ${ }^{36}$.

Czynnikiem koniecznym dla powstania samej władzy jest więc wspólnota ludzi, która musi zaistnieć materialnie, aby ta miała przestrzeń do działania. Tym samym Arendt postuluje przelotny charakter wszelkiej ludzkiej aktywności, co wskazuje nie tylko na jej podatność na destrukcję, ale także na transformacje. Jedyną pewną daną w tym założeniu jest informacja dotycząca czasu trwania danej wspólnoty i zakresu jej działania. Aktywności ludzkie mają swój początek i koniec, jednakże właśnie władza jest tym, co tworzy dla nich spoiwo. Wprawdzie konkretna władza o ustanowionym charakterze prędzej czy później kończy się, jednak ciągłe jej przemiany wskazują na pozytywny charakter nieuchronności ludzkiego działania. To dlatego właśnie Arendt krytykuje jednostki, które nie biorą udziału we wspólnym życiu (tj. polityce). Racje osoby, która nie podejmuje żadnego działania, przypominają dla niej raczej utajone motywy, które $\mathrm{z}$ jakiegoś powodu nie mogą zostać odkryte. To, co pozostaje w ukryciu, należy zaś do dziedziny prywatnej (oikos), a zatem wyraża milczącą afirmację status quo, konformistyczną zgodę na otaczającą rzeczywistość. Tym, co cechuje działanie polityczne, jest natomiast konflikt, który ujawnia subiektywne motywy i prowadzi do przekroczenia granic partykularnych interesów, do opuszczenia strefy bezpieczeństwa, jakiego wymaga konieczne otwarcie się na świat. Wolność w tym rozumieniu

${ }^{35}$ H. Arendt, Kondycja ludzka, s. 221.

${ }^{36}$ Tamże, s. 220. 
nie jest bezpieczną przystanią, ale ciągłym ruchem naprzód. To coś, co trzeba sobie wypracować we wspólnym świecie. Dlatego też Arendt nazywa bierną jednostkę „bezsilną”. Taka osoba nie posiada bowiem odwagi niezbędnej do tego, by odsłonić się przed innymi.

Trudno odmówić Arendt rzeczowej argumentacji w sprawie bezsilności jednostki, jednakże w świetle takiej interpretacji niejednoznaczne staje się pojęcie samej aktywności politycznej. Wydaje się bowiem, że niekiedy brak działania może przysłużyć się społeczeństwu bardziej niż gorączkowy arywizm. Postulat politycznej mobilizacji jest zasadny, o ile włączymy do niego założenie o rozumności wszystkich ludzi i pełnej odpowiedzialności jednostki za jej działania. Te kategorie mogą być jednak różnie interpretowane, nawet przy założeniu dobrych intencji tej grupy ludzi, która aktualnie została obdarzona przywilejem władzy. Historia pokazuje wiele przykładów politycznych ingerencji rządzących, których zamiary doprowadziły do ustrojów, gdzie pominięto podstawowe potrzeby i pragnienia jednostek. Arendt dezawuuje oczywiście wartość takiej władzy, przyznając jej miejsce $\mathrm{w}$ procesie samounicestwienia ludzkiego gatunku. Filozofka uzasadnia swoją teorię poprzez porównanie tyrana do osoby tak samo bezsilnej jak ta, która uchyla się od swoich społecznych obowiązków. Despota w jej interpretacji jest osobą bezradną, która zatraciła się w popędach, przekładając je nad dobro ogółu. W tym przypadku nie może on prowadzić prawdziwie wolnego bioi, gdyż sam siebie uczynił niewolnikiem. Tyrania opiera się bowiem na izolacji ${ }^{37}$, więc nie spełnia podstawowego kryterium władzy, czyli wielości istnień i przekonań. Tym samym bezradność nie jest jedynie cechą poddanych tyrana, ale również jego samego. Paradoksem w tej sytuacji jest to, że poprzez zdobycie całości władzy on sam faktycznie siebie jej pozbawia. Władza dla Arendt kończy się w miejscu, w którym wielość zostaje zastąpiona przez jedność oraz tam, gdzie wykorzystuje się narzędzia przemocy.

Założenie, że władza po prostu rozpada się w rękach tyrana, nie jest jednak propozycją konkretnego rozwiązania problemu istnienia ustrojów autorytarnych (bądź ich możliwego pojawienia się). W tej teorii kryje się duża dawka optymizmu i wiary w ludzkość, w miłość bliźniego i nadzieję, którą ona ze sobą niesie. Jeżeli wierzyć zaś starożytnym Grekom, każda sytuacja podlega prawom czasu i powtarza się. Doświadczenie cierpienia w pamięci narodów przypomina często jednak dogasające ognisko, w którym jeszcze

${ }^{37}$ H. Arendt, Kondycja ludzka, s. 221. 
żarzą się iskry wspomnień o konkretnych krzywdach, zbrodniach i ludziach, którzy ich dokonali. Te paleniska mogą stać się punktem zapalnym dla wielu nowych, niebezpiecznych systemów. Trzeba konkretnej politycznej zmiany, która pozwoli nowoczesnemu społeczeństwu stłumić urazy, zamiast wciąż podsycać ogień nienawiści. Także pokojowa rewolucja potrzebuje jednak fundamentów, pewnych konstruktów myślowych i wykształconych na ich polu teorii. Teoria polityki Arendt przynajmniej częściowo dostarcza takich fundamentów, oddzielając precyzyjnie kategorię władzy od powiązanych $\mathrm{z}$ nią pojęć siły, mocy i przemocy. Wskazane rozróżnienia omówimy w kolejnej części artykułu.

\section{Różnica pomiędzy władzą a przemocą - Hannah Arendt}

Początki naszych dziejów nieprzerwanie kojarzą się ze zjawiskiem przemocy. Niezależnie od tego, czy zapytamy się o „narodziny” starożytności czy kultury judeochrześcijańskiej, otrzymamy w odpowiedzi podobne mitologiczne „wyjaśnienia”: opowieść o bliźniakach karmionych przez wilczycę (gdzie Romulus zabija Remusa) bądź o skłóconej parze biblijnych braci (gdzie Kain morduje Abla) ${ }^{38}$. W obydwu historiach powtarza się mit o „założycielskiej” zbrodni. Także męczeńska śmierć Jezusa na krzyżu sugeruje, że żadna władza nie mogła mieć początku bez gwałtownego poświęcenia ludzkiego życia. Tym bardziej konieczne wydaje się utrzymywanie pamięci o tych nadzwyczajnych, kulturotwórczych aktach przemocy. Tego rodzaju mitologiczne opowieści kryją w sobie oczywiście również mroczniejsze, wysoce niepokojące przesłanie. O ile bowiem możemy jeszcze przystać na to, że u podłoża pewnych kultur prawdopodobnie tkwiła jakaś forma przemocy, o tyle sugestia (zawarta we wspomnianych mitach), że fundamentem każdej kultury i każdej organizacji politycznej musi być zbrodnia, staje się wysoce niebezpieczna ${ }^{39}$. Sugestia ta uznana przez zwolenników „siłowego” rozumienia polityki za „pewnik” zdobyła jednak ogromną popularność nie tylko w sferze politycznej działalności człowieka, ale również na polu codziennej praktyki życiowej. W opozycji do poglądu o zbrodniczych źródłach kultury musiała rozwinąć się również idea głosząca świętość życia

\footnotetext{
${ }^{38}$ Por. H. Arendt, O rewolucji, przeł. M. Godyń, Kraków 1991, s. 18.

${ }^{39}$ Tamże, s. 18.
} 
ludzkiego - trudno bowiem zaprzeczyć, że wobec realnego zagrożenia życia ono samo staje się wartością nadrzędną, wymagającą stałej ochrony. Podsycanie wartości negatywnych, jak lęk i strach, działa w obrębie powszechnej praktyki życiowej - jednostka, czując zagrożenie, automatycznie zwraca się ku instytucjom mającym rzekomo chronić życie. Właśnie w to miejsce wkroczyło chrześcijaństwo, wysuwając postulaty o świętości życia, a więc wyznaczając drogę kierującą do negacji i całkowitego odrzucenia wszelkich refleksji dotyczących legalizacji aborcji czy eutanazji. Życie samo w sobie, stając się wartością nadrzędną, usuwa możliwość kwestionowania tego założenia. To poważny zarzut w stronę religii, która w taki sposób wkroczyła w sferę polityki, na długi czas czyniąc sekularyzację praktycznie niemożliwą do realizacji nie tylko w praktyce, ale także w myśli społecznej. Wobec takich konsekwencji trudno jest zrozumieć postulaty Arendt traktujące o życiu jako wartości samej w sobie. Musimy jednak pamiętać, że jej teoria krystalizowała się w mrocznych czasach, kiedy żywym zagrożeniem były jeszcze oparte na przemocy totalitarne systemy, a samej filozofce przyświecał cel obrony życia ludzkiego przed zagrożeniami płynącymi od tych zbrodniczych ustrojów politycznych.

Siła chrześcijaństwa polega jednak właśnie na tym, że paradoksalnie odsuwa ono jednostkę od odpowiedzialności za sprawy należące do jej egzystencji. Ten system nie jest jednak wyjątkowy. Jak każda inna organizacja wiary, chrześcijaństwo sprowadza na społeczeństwo konieczność podporządkowania się. Produkując systemy panowania, obejmujące zarówno życie duchowe jak i fizyczne, zrzuca z nas ciężar konieczności namysłu nad zasadami etycznymi, które automatycznie wprowadzamy w życie. Podporządkowanie się woli takich systemów jest wygodne - można podejmować decyzje bez moralnego namysłu, przyjmując religijne prawa jako dogmaty. Jednocześnie to wszystko odbywa się przy realizacji siebie w obrębie pewnej wspólnoty. Arendt wyraża się jednak o chrześcijaństwie z dużą dozą nadziei, która dziś budzi uzasadnione obawy dotyczące zakresu jego politycznych wpływów oraz tego, w jakim stopniu religia powinna w ogóle wpływać na moralność jednostki. Filozofka pomija tę kwestię. Skupia się na odszyfrowaniu teologii chrześcijańskiej i jej strategicznych momentów, w których myślenie rozwijało się jako życie umysłu. Według Arendt chrześcijaństwo umożliwiło wykształcenie się przestrzeni politycznej, dając początek woli i pociągając za sobą dialektykę wolności. Arendt podkreśla wagę tej kategorii (woli), sytuując ją w obrębie praktyk św. Pawła i filozofii św. Augustyna. Rozważania Arystotelesa na ten temat, przeprowadzone w kontekście 
analizy relacji pożądanie-rozum ${ }^{40}$, filozofka wyjaśnia natomiast za pomocą kategorii przymusu. Wola w ujęciu Stagiryty jest sprzężona $\mathrm{z}$ działaniem umysłu, który tworzy dla niej kategorie nakazu. Natomiast chrześcijańskie ujęcie tego terminu umożliwia, według Arendt, uwypuklenie spontaniczności i przygodności ludzkiego życia, które przekształca się tutaj w ciągłe zaczynanie na nowo (początek życia), a więc w afirmację świata, gdzie podstawą są narodziny ludzkiego ciała. Według filozofki z tej pochwały życia miałoby wynikać również ogólne poczucie siły i wola mocy, które pozwalają tworzyć świadectwo ludzkiej egzystencji ${ }^{41}$.

Arendt podąża drogą woli bardzo ostrożnie, używając tej kategorii w celu uprawomocnienia tez postulujących aktywność jednostki w sferze polityczno-społecznej. Nie należy zapominać, że jej głównym założeniem jest postulat egzystencji nierozerwalnie związanej z politycznym zaangażowaniem. Dla Arendt ważny jest udział pojedynczego człowieka w projektowaniu wspólnej rzeczywistości społeczeństwa - jednostka nie może pozostać wykluczona, nieczuła i obojętna na zagadnienia świata zewnętrznego. Istotne jest, aby zachować postawę uwrażliwionego badacza, który poprzez stałe odnoszenie się do sytuacji innych ludzi i umiejscawianie siebie w nich, uprawomocnia swoje sądy, stając się czułym na kwestię krzywdy i niedoli ludzkiej. W dzisiejszym społeczeństwie przyjęła się jednakże postawa obojętności wobec drugiego człowieka. Kwestie polityczne przestały nam kojarzyć się ze sprawami, które mają realny wpływ na nasze codzienne życie. Zdaniem Arendt odszyfrowanie pojęć kojarzonych dotychczas z władzą może pomóc przybliżyć człowieka do sfery polityczno-społecznej, z której sam siebie wykluczył.

Zwróćmy uwagę na to, że takie pojęcia jak władza, moc, siła, przemoc, niemal jednogłośnie kojarzą się nam dziś z formami rządzenia. Te pojęcia zostały odsunięte od codziennej praktyki życiowej, ich użyteczność i prawdziwy sens zatarły się. Nie czujemy się już odpowiedzialni za tworzenie wspólnej przestrzeni publicznej, a więc i nasz wpływ na świat polityki został wyraźnie umniejszony. Przestrzeń polityczna powinna być miejscem, w którym każdy człowiek może dać początek nowemu działaniu. $\mathrm{Z}$ tego względu Arendt proponuje możliwość ponownego odczytania pojęć (siła, moc, władza, przemoc). Nieuzasadnione utożsamienie ich niemal wyłącznie z relacjami panowania może bowiem sprawiać, że stają się one dla jednostki obce.

\footnotetext{
${ }^{40}$ Tamże, s. 204.

${ }^{41}$ H. Arendt, Wola, przeł. R. Piłat, Warszawa 1996, s. 234.
} 
Poprzednia część tego artykułu zawierała rozważania na temat natury wła$\mathrm{dzy}^{42}$. Przypomnijmy, że dla Arendt kluczowe znaczenie miała jej potencjalność ${ }^{43}$, a także fakt, iż nie można jej zwielokrotniać, umniejszać ani zmierzyć - za to odpowiadają bowiem zjawiska siły i mocy. Władza nie zależy od wielkości. Historia pokazuje wiele przypadków, w których silniejszy materialnie władca został pokonany przez bunt ludu. Nie można jednak nigdy przewidzieć skutków takiego zakłócenia, nawet jeśli faktyczna władza ulega $\mathrm{w}$ nim rozproszeniu i zmienia się w przemoc. Właściwie nie istnieją również żadne formy rządzenia, które w całości polegałyby na panowaniu jednostki. W każdym ustroju jednak władza ma charakter jednomyślny, co zachodzi przy założeniu, że opiera się ona na jakiejś wspólnocie. Nawet król posiada doradców, którzy stanowią o jego stabilności i mają wpływ na szereg podejmowanych przez niego decyzji. Relacja między władzą zwierzchnią a ludem opiera się przecież na zaufaniu, którym ci drudzy obdarzają tych pierwszych. Dla Arendt takie uczucie może być budowane tylko dzięki zasadzie wielości przekonań. W przypadku tyranii nie możemy jednakże mówić już o żadnej władzy, lecz o jej końcu. W takim ustroju następuje bowiem skumulowanie całej mocy przez jedną jednostkę. Należy zatem wyraźnie oddzielić pojęcie „mocy” od tego, co nazywamy „rządzeniem”.

Jeżeli przyjrzymy się samemu zagadnieniu „mocy”, zauważymy, że odnosi się ono do czegoś, co znajduje się wewnątrz człowieka. Będzie to więc własność zawarta $\mathrm{w}$ osobie lub przedmiocie, która ujawnia się dopiero $\mathrm{w}$ relacji do innych rzeczy lub ludzi. Sama w sobie pozostanie jednak od nich niezależ$\mathrm{na}^{44}$. Moc to napięcie uzyskiwane na drodze przenoszenia jej własności wobec przedmiotów rzeczywistości. Istnieje jednak wyraźna różnica pomiędzy samą mocą i jej zwielokrotnieniem, a zjawiskiem przemocy, które stanowi o wyraźnym nadużyciu ze strony posiadającego „moc”.

Zanim zajmiemy się terminem przemocy, spróbujmy wyizolować z niego pojęcie samej „siły”. Arendt uważa, że powinna być ona rozważana wyłącznie okolicznościowo w ramach przynależności do zjawisk natury bądź nagłych wydarzeń, w których obserwujemy pewne formy nacisku. Oznaczać to będzie różne wydarzenia z życia człowieka, m.in. protest, bunt, ale też kradzież, szantaż czy morderstwo. Siła odnosi się więc do energii wyzwalanej poprzez

\footnotetext{
${ }^{42}$ Por. rozdział 4.

${ }^{43}$ H. Arendt, Kondycja ludzka, s. 212.

${ }^{44} \mathrm{H}$. Arendt, O przemocy, s. 57.
} 
ruchy fizyczne lub społeczne ${ }^{45}$. Ponownie rozważamy tutaj zjawisko o charakterze potencjalnym. W opozycji do niego stoi przemoc, która ma naturę instrumentalną, tzn. zawsze potrzebuje jakichś narzędzi ${ }^{46}$. Zjawisko przemocy osiągnęło tak wielkie znaczenie w dziedzinie spraw ludzkich, gdyż rozwój narzędzi pozwolił na produkcję broni. Rewolucja w technologii zaznaczyła się najsilniej właśnie w działaniach wojennych ${ }^{47}$.

Przemoc ma naturę instrumentalną i zawsze potrzebuje jakichś narzędzi albo w postaci ludzi, których wykorzystuje do realizacji swych celów, albo też w postaci przedmiotów (na przykład broni). Władza natomiast może się nimi posługiwać, jednak nie są one warunkiem jej zaistnienia. Potrzebuje ona za to uprawomocnienia, w odróżnieniu od przemocy, która posługuje się pojęciem usprawiedliwienia (również w roli narzędzia). Arendt objaśnia to za pomocą kategorii celowości. Usprawiedliwienie zawsze stanowi jakiś cel, do którego dąży przemoc. Zauważmy, że działania wojenne są obficie argumentowane w taki sposób, by zaprezentować konieczność ich rozpoczęcia. To założenie o niezbędności użycia przemocy stanowi jednak zagrożenie dla kategorii rządzenia. Arendt zwraca również uwagę, że zjawisko, które potrzebuje usprawiedliwienia, nigdy nie może stanowić istoty czegokolwiek ${ }^{48}$. Oznacza to tyle, że możemy tłumaczyć zasadność użycia przemocy w zależności od kontekstu, jednak pozostanie to zawsze usprawiedliwieniem. Przemocy nie można nigdy uprawomocnić ani twierdzić, że była ona podstawą działań.

Widzimy zatem, że władza i przemoc nie są tym samym. Jeżeli prześledzimy większość wojen czy działań rewolucyjnych, może okazać się, że przemoc pojawia się właśnie tam, gdzie władza jest zagrożona ${ }^{49}$. Z drugiej strony tam, gdzie przemoc zostaje pozostawiona własnemu losowi, obserwujemy zanik władzy. Przemoc jest absolutnie niezdolna, by stworzyć formę rządzenia. Jej legitymizacja może przynosić również inne, bardziej przerażające doświadczenie. Wskazuje bowiem na ogromną ślepotę ludzkości w kontekście rasizmu:

\footnotetext{
${ }^{45}$ Tamże, s. 58.

${ }^{46}$ Tamże, s. 8.

47 Tamże.

${ }^{48} \mathrm{H}$. Arendt, O przemocy, s. 66.

49 Tamże, s. 72.
} 
Największe niebezpieczeństwo nadciąga z innej strony; skoro przemoc zawsze potrzebuje usprawiedliwienia, eskalacja przemocy na ulicach może spowodować powstanie prawdziwie rasistowskiej ideologii mającej ją usprawiedliwićs ${ }^{50}$.

Historia pokazuje, że początek każdej zbrodniczej ideologii tkwił w przekonaniu pewnej grupy społeczeństwa, iż jest lepsza od innych. Takie założenie potrzebuje jednak pewnych „argumentów”, by nadać sobie jakikolwiek pozorny sens. Zauważmy, że często na początku ciche przyzwolenie na dyskryminację wydaje się bardzo niewinne - obraźliwe słowo czy gest w kierunku innej osoby nie sprawia przecież, że bierzemy udział w nagonce. Kiedy jednak obraźliwych słów jest więcej, stosunek społeczeństwa do sprawy przykładowo wielokulturowości państwa - zaczyna się zmieniać. Wyrasta z obojętności, potem karmi się podejrzliwością, aż rośnie i przekształca się w uczucie znacznie bardziej niebezpieczne - nienawiść, która zwykle znajduje ujście w przemocy. Ten Inny, który wydawał nam się całkiem nieszkodliwy, a być może nawet nie zauważyliśmy jego istnienia, nagle wyłania się w przestrzeni publicznej znacznie częściej niż do tego przywykliśmy. Wtedy jego widoczność sprawia wrażenie nadzwyczajnej, a liczba Innych ulega pozornemu zwielokrotnieniu. $\mathrm{W}$ ten sposób umocnione zostaje w człowieku poczucie zagrożenia. Strach to wielka siła, która wciąż szuka dla siebie nowych pojęć i rozwiązań. Jeśli pozwolimy mu wkroczyć w przestrzeń społeczno-polityczną, zajdzie w niej stopniowa racjonalizacja tego zjawiska. Zostaną wytworzone sztuczne podziały między ludźmi, natomiast sama idea człowieczeństwa, opierająca się na szacunku do drugiego człowieka, zagubi się.

W kontekście rasizmu obserwujemy największą zbieżność analiz Foucaulta z myślą Arendt. Chociaż ich sposób pojmowania władzy jest całkiem inny, możemy zauważyć u obu filozofów podobne rozumienie systemu totalitarnego. Foucault słusznie zauważa, że rasizm wpisany w nazizm zadziwiająco dobrze funkcjonował dzięki oczywistemu paradoksowi - utrzymywał, iż chroni życie poprzez postulat usunięcia innego życia (czystość rasy) ${ }^{51}$. Arendt wysuwa podobną hipotezę, pisząc o „życiu niezdolnym do życia”. Obydwoje celnie zauważają przesunięcie figury wroga, który przestał być osobą polityczną, a stał się zagrożeniem biologicznym. W ten sposób ustroje totalitarne stworzyły warunki, aby w imię urojonego bezpieczeństwa danego społeczeństwa móc nim dowolnie zarządzać. Wykorzystanie samych warunków bio-

\footnotetext{
${ }^{50}$ Tamże, s. 99.

${ }^{51}$ M. Foucault, Trzeba bronić..., s. 253.
} 
logicznych, które „określają” status jednostki w społeczeństwie, okazało się najlepszym i najstraszniejszym gwarantem władzy. I tak kategoria przemocy wpełzła w samo życie - determinując je rzekomo od początku.

Jeżeli przyjrzymy się zjawisku rasizmu, zauważymy, że nie ma chyba tragiczniejszych wydarzeń w historii ludzkości niż te, które podkreślając podziały rasowe i klasowe, doprowadziły do uprawomocnienia przemocy. Zawsze odbywało się to przy udziale podkreślenia ważności prywatnego interesu ${ }^{52}$, gdzie był on rozumiany jako realizacja pozornych wartości (np. bezpieczeństwa, komfortu materialnego). Nie ma również skuteczniejszej metody odwrócenia człowieka od jego bliźniego niż poprzez wzmacnianie w nim poczucia zagrożenia - osobistego czy też ekonomicznego. Wszelkie akty przemocy mają swój początek w zaszczepieniu społeczeństwu myśli, że Inny zagraża nam w jakiś konkretny, namacalny sposób. To założenie postuluje istnienie rzekomo naturalnego podziału ludzkości, który należy wspierać.

\section{Podsumowanie}

Najistotniejszymi osiągnięciami przeprowadzonych powyżej analiz są wglądy dokonane w teorie rządzenia M. Foucaulta i H. Arendt oraz wyprowadzone z nich wnioski, które pozwoliły na wyizolowanie przemocy z pojęcia władzy. Wierzę, że dzięki dokonanej powyżej diagnozie udało się ustalić istnienie sprzeczności pomiędzy tymi zjawiskami. Moim celem było również wykazanie dalekobieżnych konsekwencji płynących z lokowania przemocy w obrębie fenomenu rządzenia. Mam tu na myśli przede wszystkim zagrożenie ustrojami totalitarnymi, które bezsprzecznie prowadzą do zatracenia idei człowieczeństwa.

Poniższy artykuł zwraca również uwagę na kwestię politycznej bierności jednostki i związane z tym zjawiskiem zagrożenia. Była ona szczególnym powodem zmartwień oraz filozoficznych poszukiwań Arendt. Kiedy mówimy więc o praxis, nie powinniśmy kojarzyć tego terminu jedynie z melancholijnym spojrzeniem w przeszłość autorki Kondycji ludzkiej. Należy przypomnieć, że celem jej „archeologicznych” poszukiwań było postawienie dia-

\footnotetext{
52 Tamże, s. 99.
} 
gnozy współczesnego (nam/jej) społeczeństwa ${ }^{53}$. Arendt uznała zatracenie kategorii działania politycznego za równoznaczne z odebraniem człowiekowi zdolności mowy. Przyznanie gatunkowi ludzkiemu lexis było dla Greków nadaniem mu statusu człowieka. To dlatego niewolnicy i barbarzyńcy zostali jej pozbawieni, zaś samo słowo realizowało się najpełniej w przestrzeni politycznej, gdzie świadczyło o ciągłym odrywaniu się człowieka od własnej doczesności. Z upływem czasu, zwłaszcza pod wpływem chrześcijaństwa, porzuciliśmy ideał "znaczącego mówienia” w sensie politycznej praxis na rzecz kontemplacji. Spowodowało to powolne wycofywanie się człowieka ze świata polityki. Bierność zwyciężyła nad działaniem, natomiast milczenie nad mową. Obecnie problem funkcjonowania przestrzeni publicznej wydaje się wynikać właśnie z takiego stanu rzeczywistości, który cechuje ogólne poczucie słabości jednostek wobec aparatów władzy. Społeczeństwu brak zainteresowania polityką, której świat ukonstytuował się jako obcy i niedostępny. Być może problem funkcjonowania przestrzeni polityczno-społecznej udałoby się rozwiązać poprzez ciągłe uświadamianie jednostek o możliwości wprowadzenia zmian oraz zaznaczanie wielkości wpływu, jaki posiadają na otaczające ich środowisko.

Dzięki przywróconemu przez Arendt argumentowi o wartości mowy (a więc działania) człowieka można wysunąć wniosek o istniejącej myślowej opozycji pomiędzy dwiema omawianymi przeze mnie teoriami władzy. Przeciwstawna para pojęć, milczenie/głos, może być w tym kontekście omawiana poprzez pryzmat teorii Foucaulta i Arendt. Cisza charakteryzuje system stworzony przez pierwszego filozofa, natomiast postulat głosu przypada Arendt. Znaczenie tego podziału pomaga nie tylko uwypuklić istniejące pomiędzy nimi różnice $\mathrm{w}$ pojmowaniem władzy, lecz również wyodrębnić zjawisko przemocy. Brutalność wydaje się bowiem wpisana w relacje wiedza/ /władza Foucaulta, w których jednostka nie doświadcza podstawowej przynależnej jej wartości - wolności. Milczenie wobec spraw rządzenia, charakteryzujące społeczeństwo podlegające relacji wiedza/władza, wydaje się właśnie ucieleśnieniem idei przemocy, która wciska się w życie jednostek, czyniąc siebie praktycznie kategorią nieusuwalną z pojedynczego życia. To egzystencja polegająca na akceptacji określonego stanu rzeczywistości. Arendt zaznacza możliwość uwolnienia się z tego impasu myślenia o przestrzeni społeczno-politycznej, które zakłada jego wrogość i obcość. Zamiast tego proponuje

${ }^{53} \mathrm{Na}$ tę kwestię zwłaszcza zwraca uwagę Dana R. Villa w książce Arendt and Heidegger. The Fate of the Political, Princeton/New Jersey 1996. 
życie polegające na przekraczaniu własnych pragnień, ograniczeń i potrzeb, skierowane na drugiego człowieka, umożliwiające konieczne przekształcenie świata polityki w miejsce prawdziwie ludzkie.

Jednakże bardzo krzywdzące dla Foucaulta byłoby jedynie uwypuklenie różnic pomiędzy jego myślą a przekonaniami Arendt i przyznanie tej drugiej bezwzględnej racji. Zbieżne ujęcia kwestii rasizmu odkrywają bowiem jeszcze jedną ciekawą paralelę - odkrycie niebezpieczeństwa masowości. Zarówno Arendt, jak i Foucault wyrażali uzasadnione obawy wobec stechnicyzowanego społeczeństwa, w którym nowe formy wiedzy umożliwiają nowe sposoby rządzenia masami. Podzielali również „wspólny” pogląd dotyczący samego rozumienia tego nowego zjawiska. Musimy bowiem zrozumieć to, co obydwoje starali się nam przekazać i co stanowi niejako most pomiędzy ich sposobami rozumienia władzy. Społeczeństwo masowe jest zagrożeniem, które umożliwia nowe formy panowania. Fantazja wspólnego losu i celu, w której wszystkie jednostki dążą do realizacji wyimaginowanych pragnień, służy do zamaskowania swojego prawdziwego przeznaczenia, którym jest zniszczenie więzi społecznych i totalne podporządkowanie jednostek ${ }^{54}$.

Ta przykra konkluzja może jednak pokazać dwie drogi rozwoju nowoczesnych społeczeństw oraz form rządzenia. Foucault prezentuje ścieżkę, w której człowiek zostaje pozbawiony wyboru - jest wrzucony w relacje panowania. One zaś sprowadzają na niego osamotnienie i bezbronność. Arendt podaje człowiekowi rękę i wyciąga go z więzienia samotności, proponując w zamian ludzkie współbycie. To pękniecie jest widoczne jednak dopiero wtedy, gdy porzucimy termin przemocy i przestaniemy używać go jak narzędzia do opisu każdej relacji społeczno-politycznej. Akcentowanie zjawisk przemocy jest ważne, jednak ważniejsze jest przeciwdziałanie im. Ludzka troska i współczucie są dla filozofki bardziej znaczące niż opis politycznych struktur. To te terminy stara się wplatać w swoje pojęcie polityczności. W ten sposób Arendt przedstawia człowiekowi nowe możliwości w świecie, w którym wszystko podlega prawom powtórzenia i czasu. Oto historia o wiecznym początku, który ujawnia się poprzez słowo i czyn ${ }^{55}$.

\footnotetext{
${ }^{54}$ P. Sosnowska, Arendt i Heidegger..., s. 325.

${ }^{55}$ Arendt historię o wiecznym początku przejęła od św. Augustyna. Korzenie totalitaryzmu kończy jego słowami: Initium ut esset homo oreatus est. Por. H. Arendt, Korzenie totalitaryzmu, przeł. D. Grinberg, M. Szawiel, Warszawa 2012, s. 670.
} 


\title{
Bibliografia
}

Arendt H., Kondycja ludzka, przeł. A. Łagodzka, Warszawa 2000.

Arendt H., Korzenie totalitaryzmu, przeł. D. Grinberg, M. Szawiel, Warszawa 2012.

Arendt H., O przemocy. Nieposłuszeństwo obywatelskie, przeł. A. Łagocka, W. Madej, Warszawa 1998.

Arendt H., O rewolucji, przeł. M. Godyń, Kraków 1991.

Arendt H., Wola, przeł. R. Piłat, Warszawa 1996.

Butler J., Uwikłani w płeć, przeł. K. Krasuska, Warszawa 2008.

De Beuvoir S., Druga płeć, przeł. G. Mycielska, M. Leśniewska, Warszawa 2014.

Czerniak S., Michalski R., Filozofia jako samokrytyka rozumu. Meandry doktrynalnej ewolucji teorii krytycznej, Lubicz 2014.

Foucault M., Nadzorować i karać, przeł. T. Komendant, Warszawa 1993.

Foucault M., Trzeba bronić społeczeństwa, przeł. M. Kowalska, Warszawa 1998.

Foucault M., Rządzenie żywymi, przeł. M. Herer, Warszawa 2014.

Kristeva J., Geniusz kobiecy. Hannah Arendt. Biografia, przeł. J. Levin, Warszawa 2007.

Lorenz K., Tak zwane zło, przeł. A. Tuszyńska, Warszawa 1972.

Nietzsche F., Wola mocy. Próba przemiany wszystkich wartości, przeł. S. Frycz i K. Drzewiecki, Kraków - Warszawa 1910.

Platon, Państwo, przeł. W. Witwicki, Warszawa 1958.

Sartre J. P., Byt i nicość, przeł. J. Kiełbasa, Kraków 2007.

Sosnowska P., Arendt i Heidegger. Pedagogiczna obietnica filozofii, Kraków 2015.

Villa Dona R., Arendt and Heidegger. The Fate of the Political, Princeton, New Jersey 1996.

\begin{abstract}
The Notion of Power in the Views of Michel Foucault and Hannah Arendt

The article is a polemical deliberation on Michel Foucault's and Hannah Arendt's theories of power. It is mainly focused on the reconstructing the Arendt's views on the governing. It also shows the need of breaking the relationship between power and violence basing on Arendt's concept. This leads to comparison of two different ways of understanding of the power and the governing.
\end{abstract}

Key words: power, violence, governance, political philosophy, action 